\title{
ANALYSIS OF ANTHROPOGENICALLY INDUCED CHANGES IN ECOSYSTEM COMPONENTS IN THE KATUN RECREATIONAL AREA OF THE ALTAI REPUBLIC, RUSSIAN FEDERATION
}

\author{
Peter Yu. MALKOV* \\ Gorno-Altaisk State University (GASU), Department of Biology and Chemistry, \\ Gorno-Altaisk, Russian Federation, e-mail: malkovi@bk.ru \\ Tatyana N. KURILENKO \\ Gorno-Altaisk State University (GASU), Department of Biology and Chemistry, \\ Gorno-Altaisk, Russian Federation, e-mail: kurilenk05045@yandex.ru

\section{Maria G. SUKHOVA} \\ Gorno-Altaisk State University (GASU), Department of Geography and \\ Nature Management, Gorno-Altaisk, Russian Federation, e-mail: mar_gs@ngs.ru
}

\section{Olga V. ZHURAVLEVA}

Gorno-Altaisk State University (GASU), Department of Geography and Nature Management, Gorno-Altaisk, Russian Federation, e-mail: juravolg@mail.ru

\section{Alexander I. MINAEV}

Gorno-Altaisk State University (GASU), Department of Geography and Nature Management, Gorno-Altaisk, Russian Federation, e-mail: minaev-alex@yandex.ru

\begin{abstract}
Citation: Malkov, P.Yu., Kurilenko, T.N., Sukhova, M.G., Zhuravleva, O.V., \& Minaev, A.I. (2019). ANALYSIS OF ANTHROPOGENICALLY INDUCED CHANGES IN ECOSYSTEM COMPONENTS IN THE KATUN RECREATIONAL AREA OF THE ALTAI REPUBLIC, RUSSIAN FEDERATION. GeoJournal of Tourism and Geosites, 26(3), 769-779. https://doi.org/10.30892/gtg.26308-396
\end{abstract}

\begin{abstract}
The aim of the research is a comprehensive evaluation of the character of the impact of recreational activity and tourism on the biological communities of the Republic of Altai. The article discusses the main tendencies of changes in biological communities in the Altai Mountains proper to places of high recreational load. It is shown that as a rule, changes are manifested in the impoverishment of biological diversity, local extinction or decrease of the number of stenotopic bank types and the extension of the spatial distribution anthropoperseverant species. The general regularities and specificity of the reaction of the researched groups of organisms are demonstrated.
\end{abstract}

Key words: sustainable tourism, ecosystems, mountain areas, biological diversity

\footnotetext{
* Corresponding author
} 


\section{INTRODUCTION}

Tourism and recreational activities are usually seen as a viable alternative to other more destructive forms of environmental management, such as mining, timber harvesting and agriculture. Tourism normally helps to increase the employment of the local population, which favourably affects the social environment.

In addition, the development of tourism can serve as an important mechanism for the economic provision for specially protected natural areas, especially national parks (Travkina, 2002). On the other hand, negative manifestations caused by a direct impact of recreation and tourism are well known; their scale and severity require solutions at international level (Bratanovsky et al., 2014). These attributes define tourism as a dual phenomenon that is a "double-edged sword for social and ecological development" (Van der Duim \& Caalders, 2002). On the cusp of the $20^{\text {th }}$ and $21^{\text {st }}$ centuries, there is an active search for ways of sustainable development all over the world when an important concept of "sustainable tourism" was formulated as a kind of tourism that ensures its viability over an infinitely long period of time (Butler, 1999).

The goal of sustainable tourism is to find a balance between environmental protection, preservation of cultural integrity of ethnic groups, social justice and economic benefits, as well as to meet the needs of the population in terms of living standards, both in the short and long-time perspective. At the moment, a need for comprehensive development of sustainable tourism is expressed at the level of the UN General Assembly resolution that encourages "intensified efforts on regular evaluation of the role of sustainable tourism, including ecotourism, in appropriate cases, so that more informed decisions can be made at the local and national levels, widely reproduce and apply the experience gained, especially in the context of other economic activities, and use innovative technologies to relieve social, cultural and environmental impacts of tourism" (Zhuravleva et al., 2018). The development of promising forms of sustainable tourism also involves monitoring of the state condition of the environmental biological component. This is largely due to the fact that recreational areas are usually unique natural objects characterized by an increased concentration of biological diversity, often combined with the presence of rare and endemic components. Therefore, the preservation of this diversity is both a prerequisite of the stability of recreational areas and a significant factor of their increased attractiveness for holidaymakers (Sukhova et al., 2018).

The patterns of changes in biological communities under the influence of tourism and recreational activities in the framework of this study are discussed using the example of the Altai Republic as one of the important centers of tourism and recreational industry in Russia. The number of tourists arriving at the territory of the republic increases every year and in 2017, according to data of the AR Government, it reached 2.05 million people. Maximum tourist flows are seen in the valley of the Katun River in the Mayminsky and Chemalsky districts, where more than half of the tourist enterprises of the Altai Republic are concentrated. In 2017, 64.8\% of tourists who visited the Altai Republic visited these districts. Based on the natural and climatic characteristics, the Katun Nature Reserve was created in this part of the Altai (Sukhova et al., 2014).

\section{METHODOLOGY}

Katun recreational area is within Mayminsky and Chemalsky administrative districts of the Republic of Altai (Figure 1). The territory belongs to North-Altai physicalgeographical region of Gorno-Altai Autonomous Oblast which is a part of Altai-Sayan mountain country. Orographic base is the spurs of two major submeridional ridges Seminsky and Iolgo. A characteristic feature of the orography of North Altai, which 
determines the main features of its microclimate and natural landscapes, is a combination of narrow and wide dividing ridges and valleys with a high degree of erosion dismemberment, especially in the sides of the valleys of large rivers (Novikov, 2004).

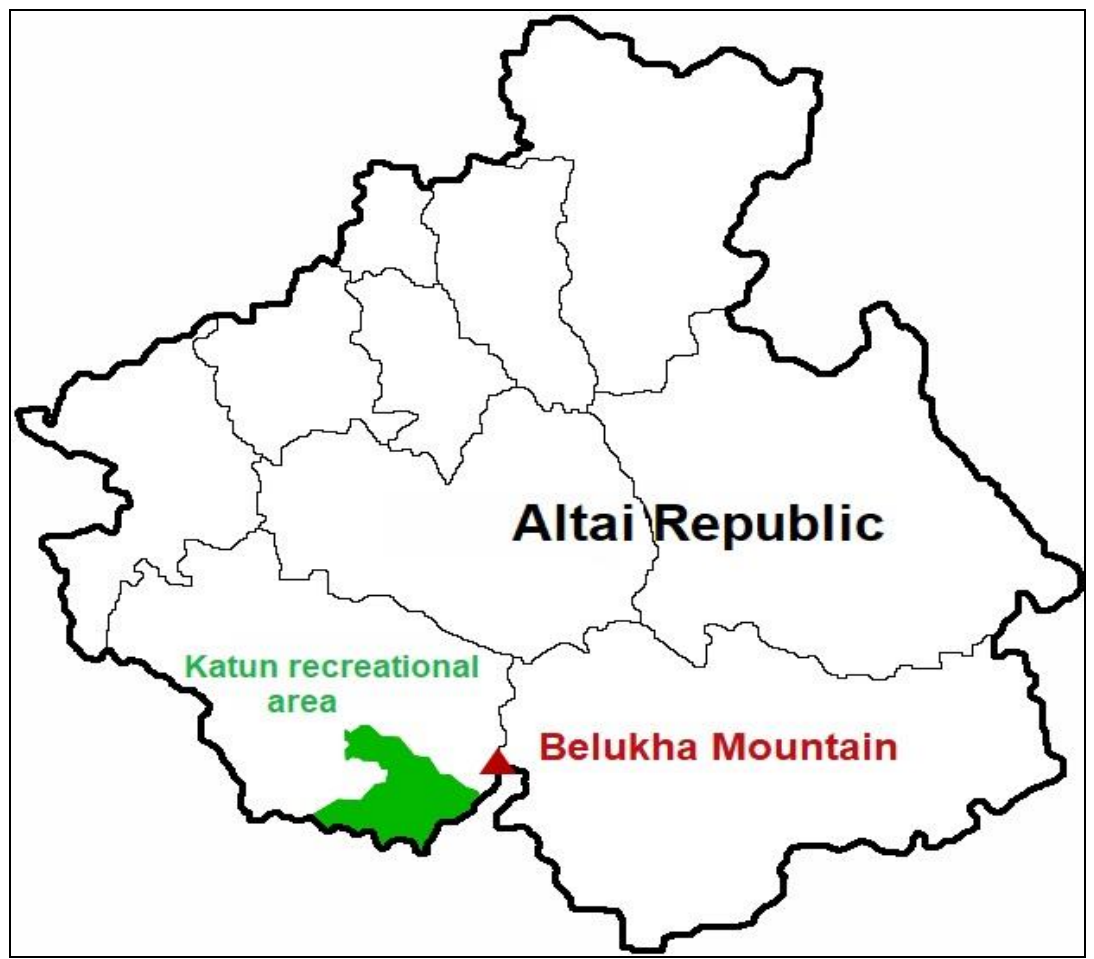

Figure 1. Geographical location of the Katun recreational area

The area is characterised by the general decrease of the height of the area in the Northern direction, namely, from the middle mountains in its Southern and central part to the low mountains in the extreme Northern part. The following main genetic types of terrain are singled out in the geomorphological structure: low-mountain and mediummountain erosion-denudation, low-mountain erosion-accumulative with elements of tectonic-accumulative terrain (Shchukina, 1960). The valley of the Katun River is a "wind tunnel" of Altai. An air flow under the impact of the baric gradient passes through the ridges, falling on the valley bottom, adiabatically heats and takes the properties of fohns. Fohns are most typical of the cold season (90-100 cases during the year).

In January, average temperature is $-12-(-16)^{\circ} \mathrm{C}$. However, the average wind speed in the valley is 4 or $5 \mathrm{~m} / \mathrm{sec}$, so average monthly conventional temperature is -18 $-(-20)^{\circ} \mathrm{C}$, at $1 \mathrm{pm}$ is $-13-(-16)^{\circ} \mathrm{C}$. The presence of fohns affects the structure of the weather types. In winter months, the prevailing weather is moderately severe, it is $30-$ $50 \%$; mild weather is $20-25 \%, 10-15 \%$ is the weather with positive temperatures.

The frequency of severe weather in the coldest months does not exceed $20 \%$; very severe weather is not observed. In July, average temperature is $17-19{ }^{\circ} \mathrm{C}$, equivalent effective temperature (EET) is $12-15^{\circ} \mathrm{C}$, at $1 \mathrm{pm}$ is $20-21^{\circ} \mathrm{C}$. In May and September, cold weather of V-VI types makes up about 25\%, repeatability of comfortable weather is 15 or $20 \%$ and about $15 \%$ repeatability of hot weather. In summer months (July - August) 
comfortable weather is $30-40 \%$ or more, cold weather is $5-10 \%$ The daily course of weather types is expressed very clearly. In the daytime, warm and hot weather, at night this weather disappears, the greatest repeatability is typical cool weather.

The favourable bioclimatic conditions indicator in winter months is $0.70-0.80$, in summer is 0.70-0.72, in spring and autumn is 0.30-0.50. During the year, the number of days with favourable weather for the human body is 220-230. According to the degree of comfort of bioclimatic conditions, the area is comfortable. The functional voltage of the thermoregulation systems is mainly minimal and weak, and to a lesser extent, average.

The main watercourse of the area is the Katun River presented by its lower course. It is flown into by more than 40 medium and small rivers and streams, the main of which are the Rivers of Maima, Sema and Chemal. The width of the Katun River valley in the area territory varies from 0.5 to $3 \mathrm{~km}$. The river's depth is to $4-5 \mathrm{~m}$, in low water period is to $1.5-2 \mathrm{~m}$. The average flow velocity is $0.3 \mathrm{~m} / \mathrm{s}$ during low water period and increases to $1.7 \mathrm{~m} / \mathrm{s}$ during flood. The rivers of the district are characterised by spring and summer floods. Nutrition is mixed from melting snow (40 \%), ground (40 \%) and rain (20 \%) waters. During rain freshets, discharge of rivers can be higher than during the flood.

The comfort of bioclimatic conditions, exceptional attractiveness of landscapes and transport accessibility make the area very promising for establishing health resorts and the organising various types of tourism. However, tourism should be of ecological character to preserve the biodiversity of the area.

The range of the studied model groups of organisms:

- vegetation cover and flora are the main producing component of any terrestrial ecosystem and the basic level of nutrition chains;

- earthworms (Lumbricidae) are one of the most convenient groups of organisms for studying the features of structural changes in mesobiota pedofauna;

- orthopteroid insects (Orthoptera) - despite relatively small number of species, orthopteroid insects, in particular locusts which are mainly phytophagous organisms, that is, primary consumers, play an extremely important role in the functioning of biogeocenoses, especially steppe and meadow ones, including those which experience a large anthropogenic load;

- day butterflies (Hesperioideae, Papilionideae) are a multi-species group, diverse in phenology, abundance and biocenotic significance, a traditional object of monitoring research;

- vertebrate animals (Vertebrata) are a multi-species group, diverse in its nutritional adaptation, phenology, abundance and biocenotic significance, a traditional object of monitoring research (amphibians, reptiles; birds, small mammals).

In determining the above-ground phytomass of grass cover, the method of accounting sites laid by the method of random sampling was used (Rysin \& Zolotova, 1968). The air-dry mass was determined with following recalculation per 1 hectare. The traditional sweep-net method (entomological net was used) was applied to determine the abundance of orthopteroid insects. It is common knowledge that the results of catching for fifty waves, reflect the density of orthopteroid insects per $1 \mathrm{~m} 2$ of grassy surface (Kashkarov, 1933; Sergeev, 2009). Butterflies were accounted by the route method on transects. The transect method, unlike methods of accounting sites and labeling imposes less strict requirements for the type of distribution of a species inside station (Hall, 1985).

At every of the investigated sites they walked 2 or $3 \mathrm{~km}$. The specified route length is representational for the evaluation of the abundance of individual species if they repeatedly come across during the route (Thomas, 1983) as well as for the evaluation of the total abundance since a set of single species is a small part of the total 
population density. The transect width was determined for every species individually by doubled average detection range (Malkov, 1994, 2005). The accounting of birds is carried out on permanent, but not strictly fixed routes without limiting the width of the transect in accordance with the methodological requirements set out in special research papers (Ravkin et al., 1999; Ravkin \& Livanov, 2006). Small mammals were accounted with the help of Gero traps equiped with standard lures (bread moistened with unrefined vegetable oil) by the method of traps and lines, there was one hundred traps in every landscape, on every site and in each time season. The state of the communities was evaluated based on the analysis of the number of discovered species, total abundance and Shannon and Simpson Diversity Indices. The diversity indices take into account two components, namely, species richness and uniformity (equitability) the contribution of species to total abundance, the more species and higher the uniformity, the more diverse and structurally complex community is considered to be. The first of the indices is more sensitive to changes of the number of species, especially at low species richness, the value of the second one is affected most by abundant species (Pesenko, 1982).

The evaluation of the statistical reliability of differences of the diversity indices was performed with the help of resampling and a permutation test (Shitikov, 2012) with 9999 randomisations. All calculations were performed using Microsoft Excel and Paleontological Statistics (Hammer et al., 2001). The bulk information that served as an empirical base for generalization was collected during complex expeditions to the control and recreation-exposed areas of the main landscapes of the Katun Nature Reserve. As a result of quantitative counts, data were obtained on the abundance (density) of species of clavaceous lepidoptera (diurnal butterflies) and orthopterans, amphibians, reptiles, birds, small mammals, resources of superterraneous biomass of herbage cover and earthworms (lumbricide). Materials were partially published (Vozniychuk, 2016; Laptev et al., 2016; Malkov, 2016; Khudyakova et al., 2016). The proposed publication is an attempt of a comprehensive analysis of changes occurring in biological communities as a result of the impact of tourism and recreational environmental management.

\section{RESULTS AND DISCUSSION \\ Analysis of density and diversity of biological species in the territory of the Altai Republic}

Herbage cover and earthworms. The data obtained during the expeditions suggest that the superterraneous biomass of herbage cover and earthworms in the areas with increased recreational burden is normally decreased compared to those not subjected to the influence of the recreational factor. At the same time, statistically significant differences were observed in the herbage cover only; as for lumbricidea, they manifest themselves only as a trend (Laptev et al., 2016). Less pronounced differences in the lyumbricide biomass between the sites with and without recreational impact, in our opinion, are due to the greater stability of the soil environment compared to the ground-air one. A high content of organic matter of the soil, as well as a relatively low level of daily and seasonal fluctuations in temperature and chemical composition, apparently compensate for the negative impact of the recreational factor.

Excessive recreational load causes a change of species composition, especially noticeable in meadow communities. As a rule, this is manifested in the emergence of semi-ruderal plants such as Rhinanthus minor, Verbascum densiflorum, various species of eyebrights Euphrasia, rosette forms of dandelions Taraxacum, plantains Plantago and meadow weeds Echium vulgare, Nepeta sibirica, Prunella vulgaris, Lamium album. From other species on degraded meadows one can note a mass 
development of Achillea millefolium, Alchemilla vulgaris, Geranium pratense, Potentilla anserina, Polygonum aviculare, Trifolium repens, Capsella bursa-pastoris. In the areas of meadow communities which are not affected or weakly affected by anthropogenic activity the flora does not contain these species or they are single. From the permanent types of such communities one should note Phleum pratense, Alopecurus pratensis, Poa pratensis, Bistorta officinalis, Geum rivale, Sanguisorba officinalis, Trifolium pratense, Origanum vulgare, Tragopogon pratensis, various species of bloodroots Potentilla, meadow rues Thalictrum, forget-me-nots Myosotis and others.

Orthopterans. Orthopteran communities of the Katun Nature Reserve react to the tourism and recreational impact by qualitative and quantitative reorganizations of the species composition and structure. Comparison of intra-landscape differences between the control and recreational areas shows that the latter, as a rule, are covered by a large number of species. In particular, in forest biotopes, anthropogenic changes in the herbage cover structure allows a high density of the northern steppe and meadow species Conocephalus dorsalis, Glyptobothrus biguttulus and Chorthippus apricarius. In the meadows of the Katun valley exposed to recreational activities, a relatively high density of polyzonal Chorthippus albomarginatus and Locusta migratoria (Figure 2), as well as two non-moral species, Stethophyma grossum and Mecostethus alliaceus, is observed. The density of their populations in similar biotopes, but mildly disturbed recreation sites, is noticeably lower, or they are not found there at all. In some situations, a high level of recreational exposure can lead to more complex adjustments. On dry meadows, Euthystira brachyptera, Stenobothrus lineatus, Megaulacobothrus aethalinus and Conocephalus dorsalis drop out of the community but the density of Metrioptera brachyptera, Psophus stridulus and Chorthippus apricarius increases.

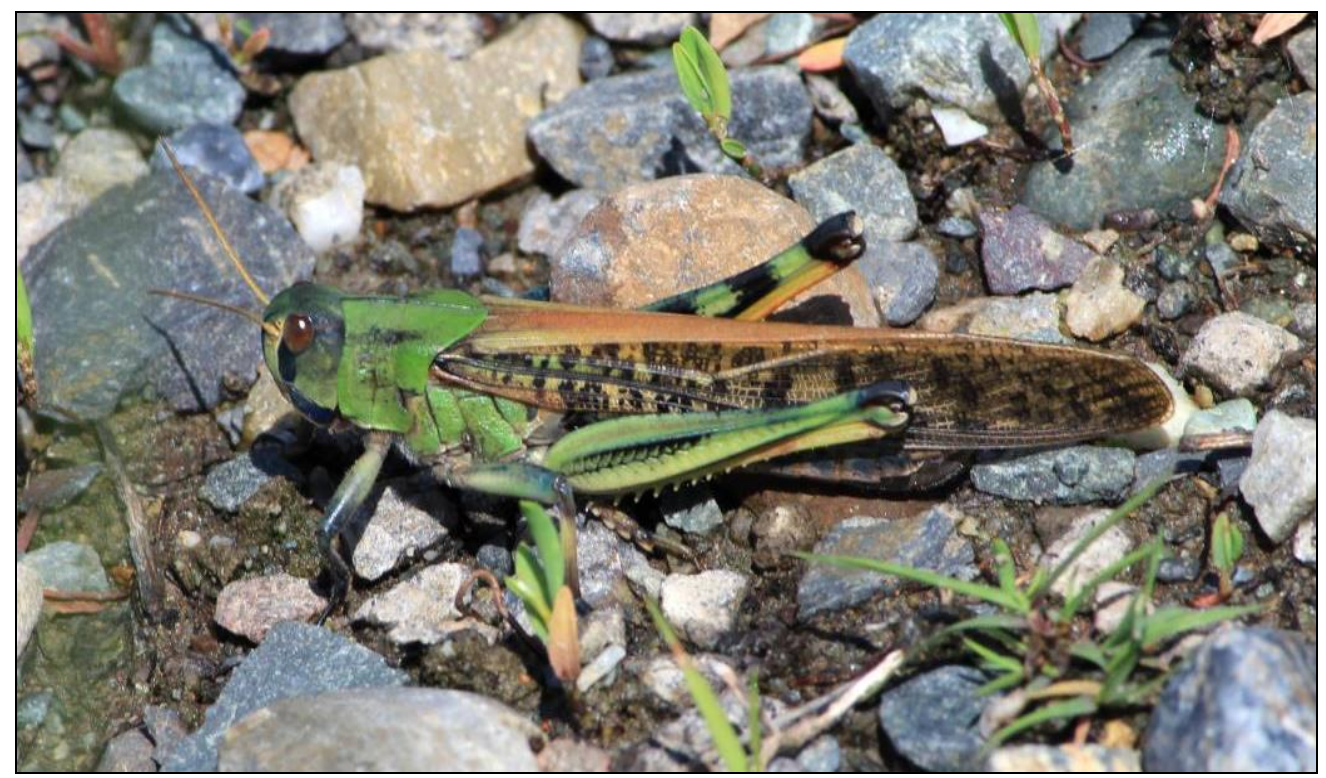

Figure 2. Locusta migratoria Linnaeus, 1758 (photo by N.E. Khudyakov)

Therefore, depending on the landscape type, the recreational factor can both increase the distribution range and the number of certain species of orthoptera and have a negative limiting effect. Local disappearances or reductions in the number of stenotopic 
species of orthoptera in recreational areas are, as a rule, compensated by the population of new, more anthropotolerant elements (Khudyakova et al., 2016).

Diurnal butterflies. A clear trend towards a reduction in the butterfly species richness under the influence of recreational activities was observed. To a large extent, this refers to the Katun Nature Reserve meadow biotopes, which are normally characterized by Meltiaea athalia, M. latonigena metalmarks, Clossiana dia pearl butterfly (Figure 3), Cl. euprhosyne, Coenonympha glycerion chestnut heath, Maculinea teleius and Plebejus argus blues. An increased recreational burden results in a sharp decrease in their abundance, in some places local extinction. The species composition of the population of clavaceous lepidoptera in forest biotopes is generally more resistant to the recreational burden. In addition, due to the reduction in the density of tree-shrub undergrowth, an increase in mosaic elements, mainly paths, unpaved roads and small grass fields, some meadow species penetrate forest recreational areas. However, even in this case, species of butterflies that were absent in the recreational areas were found, compared to usual and even numerous in the control areas. These include, in particular, Argynnis sagana pearl butterflies (Figure 4), as well as Carterocephalus silvicolus, Polygonia c-album, Erebia ligea and Celastrina argiolus (Malkov, 2016).

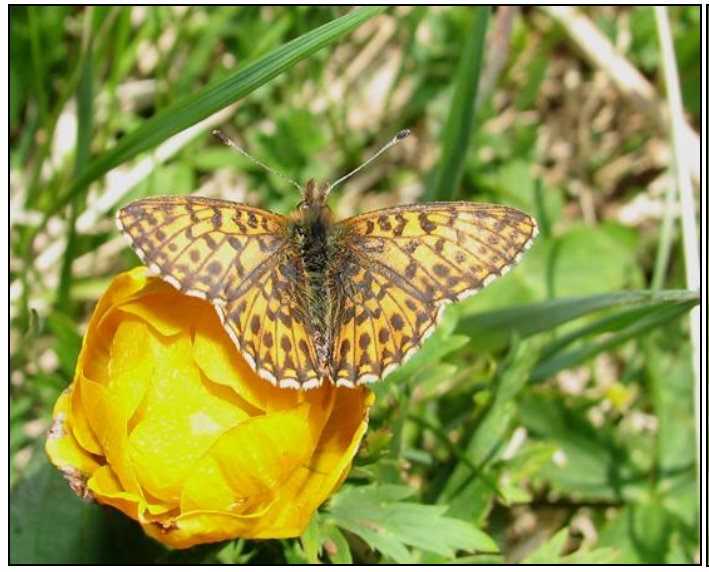

Figure 3. Clossiana dia (Linnaeus, 1767)

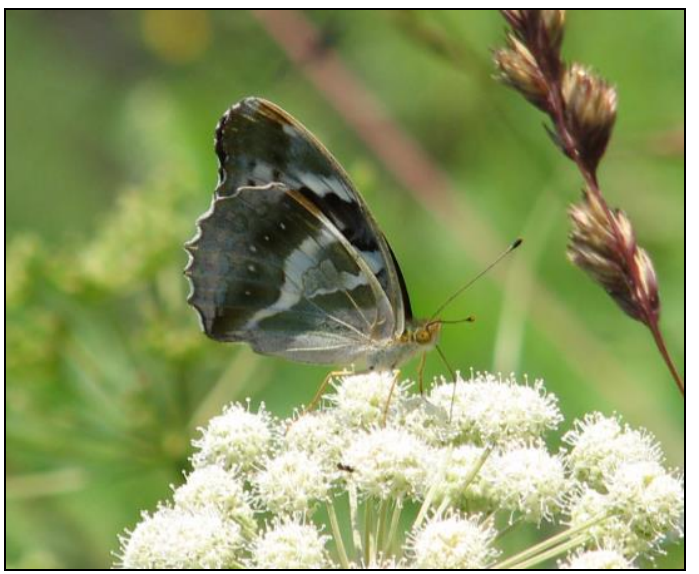

Figure 4. Argynnis sagana Doubleday, 1847

Amphibians and reptiles. An ambiguous reaction of the amphibian and reptile communities to anthropogenic pressure was observed. At the same time, the nature of changes in the communities depends on the intensity of recreational use of natural resources and on the degree of moistening of habitats. Under moderate and low moistening, recreation adversely affects the amphibian and reptile communities and on wetlands, on the contrary, increases the range of distribution and number of most species (Vozniychuk, 2016). Birds. The nature of changes in ornitocomplexes of the Katun Nature Reserve also depends to a large extent on the type of habitat. In forest biotopes, the species diversity of birds decreases under the influence of the recreational factor. The following species demonstrate a decrease in abundance under tourism burden - Buteo buteo buzzard, Bonasa bonasia grouse, Streptopelia orientalis eastern turtledove, Dryocopus martius black woodpecker, Dendrocopos major spotted woodpecker, Anthus trivialis tree pipit, Lanius colluruo red-backed shrike (Figure 5), Luscinia common nightingale, Luscinia calliope red-necked nightingale, Turdus pilaris fieldfare (Figure 6), Phylloscopus trochiloides green hemlock, Periparus ater coal tit. Among meadow biotopes, such an 
obvious reduction in the abundance of birds is not observed, but there the number of the optional synanthropus, the common magpie Pica pica, increases significantly.

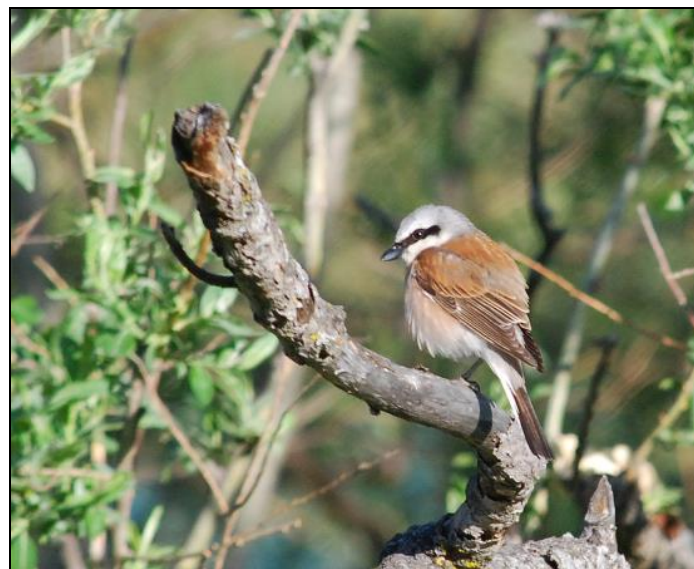

Figure 5. Lanius colluro Linnaeus, 1758

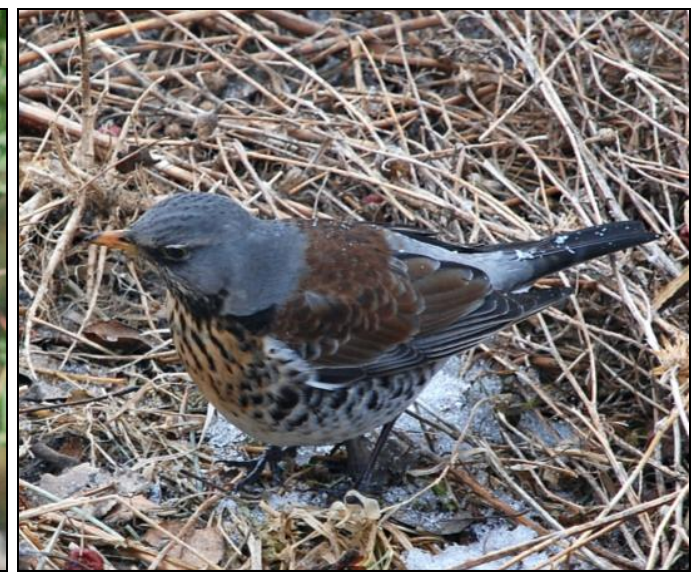

Figure 6. Turdus pilaris (Linnaeus, 1758)

Small mammals. The analysis of distribution of small mammal species across natural landscapes and their deviates in some cases demonstrates an ambiguous situation when a particular species in one type of habitat was found only in the areas exposed to anthropogenic pressure, and in another biotope, only in the control areas. This mainly refers to shrews. As for the rodents, the Asian Chipmunk Tamias sibiricus (Figure 7), the common hamster Cricetus cricetus, the small forest mouse Apodemus uralensis, the gray red-backed vole Myodes rufocanus and the root vole Microtus oeconomus show a steady tendency to avoid places with an increased concentration of tourists and recreational impact.

\section{Features of tourism impact on biological diversity}

The analysis shows a number of changes occurring in the communities of various groups of organisms resulting from the intensive impact of tourism and recreation in the Katun Nature Reserve of the Altai Republic. The nature of rearrangements in the studied groups is not expected to coincide in detail, since they differ significantly in evolutionary and ecological terms, but the overall focus normally remains the same, i.e. a reduction in the abundance of the species most sensitive to anthropogenic impact. In the orthopteran and clavaceous lepidoptera communities, as well as among part of birds, these changes are partly compensated by the appearance or increase in the abundance of more anthropotolerant elements, however, such rearrangements are not evidence of stability, but, on the contrary, can have serious negative consequences.

The above changes are not the only emerging environmental problems in the Katun Nature Reserve. The ARI "Ecology" employees, in a series of studies during 20122015, based on the quantitative data on the ground cover digression and recreational burden in places of unorganized recreation (Report on the research project..., 2012; Pavlova, 2015; Pavlova et al., 2013), believed that if the existing trends persisted by 2018, self-regeneration of the ground cover at some sites of the Katun Nature Reserve would be impossible. Without engaging in a discussion regarding self-regeneration, we would note that the situation has worsened since that time, as predicted by them. The same authors noted an increase in the number of dry and severely weakened trees in the areas of mass recreation, as well as the accumulation of siderophile ( $\mathrm{Ti}, \mathrm{V}, \mathrm{Mn}$ ), chalcophile (Ni, $\mathrm{Cu}, \mathrm{Zn})$ and biogenic (P, B) elements in the foliage (Pavlova et al., 2012). 
Analysis of Anthropogenically Induced Changes in Ecosystem

Components in the Katun Recreational Area of the Altai Republic, Russian Federation

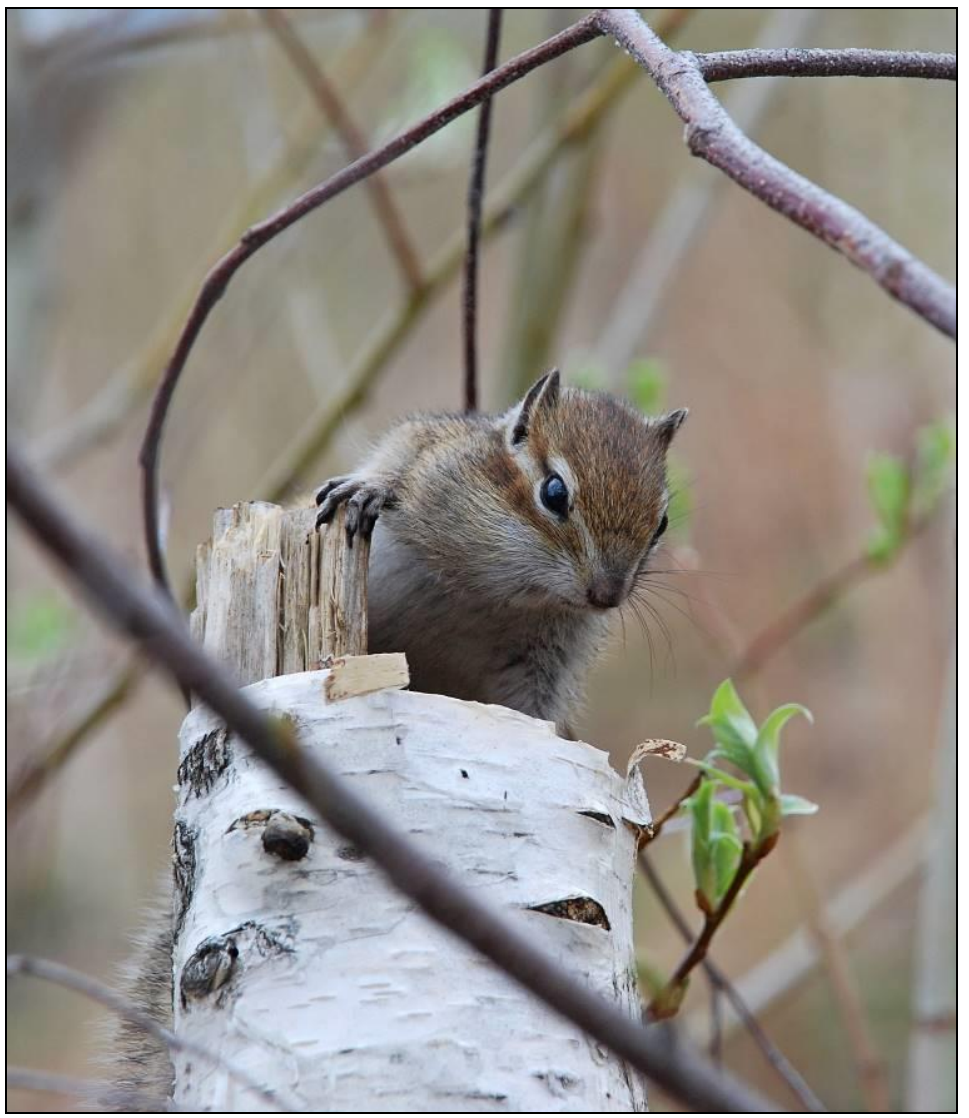

Figure 7. Tamias sibiricus (Laxmann, 1769)

Negative aspects of the impact of tourism development in the Altai Republic on ungulate populations are discussed in the work of Yu.N. Kalinkin (2012). The main focus of this publication is poaching, commercial hunting and, only partly, a disturbance factor, which is completely true for the eastern and southern part of the Altai Republic. In the conditions of the Katun Nature Reserve, a disturbance factor, in our opinion, is of paramount importance, since there is significantly higher concentration of tourists. Some of them have offroad vehicles, including ATVs and snowmobiles, which greatly expands the possibilities of movement. It is important that the territory of the Katun Nature Reserve is one of the main ways of seasonal migrations of the Siberian roe deer Capreolus pygargus from the foothill part of Altai to the hinterlands (autumn) and back (spring) (Sobansky, 2008). Therefore, the tourism and recreational sector has become a significant factor of a negative impact on the environment of certain territories of the Altai Republic. Irrational operation leads to the destruction of their potential.

At the same time, a unique recreational resource of the Altai Republic is one of the very few among those involved in its economy and competitive on the Russian and world markets. The actual task, in our opinion, is to create economic (tax) and informational conditions for spending part of the funds of tourist companies to support the ecological conditions of the territory, which is not actually reflected even as a recommendation. This situation is due to the fact that the bulk of tax deductions goes to the budget of the 
regions where travel agencies are officially registered (Altai Krai, Novosibirsk and Kemerovo region, Moscow), and the republic receives funds only from the lease of land plots, occupied by the objects of tourism and recreational infrastructure. Improvement of the situation can occur with the full support of sustainable tourism, carried out mainly by the residents of the Altai Republic, especially since the interest in "green" tourism, in particular, living in rural houses, is increasing, as well as with the proper redistribution of tourist flows to the Central and Southeast Altai.

\section{CONCLUSION}

This article analyses the biological diversity of the Altai Republic. The impact of tourism and recreational activities on the natural ecosystems of the Altai is discussed. It is established that the number of amphibians depends not only on the degree of the territory's moisture, but also on the intensity of recreational load. This study was aimed at the development of a framework for a comprehensive assessment of the potential of the territory, including the assessment of natural conditions and resources, anthropogenic and recreational development, ecological conditions of the area and the impact of tourism on these components. Recreation and tourism are the main strategically important areas of regional development. A special economic zone of tourism and recreational type is created in the territory of the Republic. The bas is for its creation was a unique recreational potential and natural importance. This will ensure the development of the economic potential of the Altai Republic but, at the same time, the need to preserve the historical and natural heritage of the republic, social development and sustainable use of natural resources deserve attention.

The following species were studied during complex expeditions: earthworms, orthopteran insects, diurnal butterflies, amphibians and reptiles, small mammals. It was established that the number of amphibians depended both on the intensity of the recreational burden and a degree of moistening of the territory. The development of tourism may also lead to the reduction in some insect species (Euthystira brachyptera, Stenobothrus lineatus, Megaulacobothrus aethalinus, Conocephalus dorsalis, Meltiaea athalia, M. latonigena, Argynnis sagana, Clossiana dia, Cl. Euprhosyne, Coenonympha glycerion, Maculinea teleius) and increase in the distribution of others (Metrioptera brachyptera, Psophus stridulus and Chorthippus apricarius). The study analyses the changes that occur in the communities of various biological species. The negative impact of tourism on the environment is due to the irrational exploitation of recreational areas. At the same time, negative changes prevail, causing significant and increasing damage to it. The resolution of this problem requires a systematic approach, which would include a variety of interrelated measures while using natural resources for tourism purposes. Such interventions imply the use of additional technical, organizational, sociological, resource management and environmental knowledge.

\section{Aknowlegments}

The work was done within the framework of the state task of the Ministry of Education and Science of the Russian Federation 5.5702.2017/8.9.

\section{REFERENCES}

Bratanovsky, S.N., Bratanovskaya, M.S., \& Kocherga, S.A. (2014). Legal Regulation of Tourism in the Russian Federation. Moscow: Direkt-Media.

Butler, R. (1999). Sustainable Tourism: a State-Of-The-Art Review. Tourism Geographies, 1(1), 7-25.

Gall, L.F. (1985). Measuring the Size of Lepidopteran Populations. Journal of Research on the Lepidoptera, 2(24), 97-116. 
Analysis of Anthropogenically Induced Changes in Ecosystem Components in the Katun Recreational Area of the Altai Republic, Russian Federation

Hammer, Ø., Harper, D.A.T., \& Ryan, P.D. (2001). PAST: Paleontological Statistics Software Package for Education and Data Analysis. Palaeontologia Electronica, 4(1), 1-9.

Kalinkin, Yu.N. (2012). The Impact of Tourism Development on the Ungulates of the Altai Republic. Modern problems of nature management, hunting and fur farming, 1, 39-40.

Kashkarov, D.N. (1933). The Environment and the Community (Basics of Synecology). Moscow: State Medical Publishing House.

Khudyakova, N.E., Malkov, P.Yu., \& Khudyakova, T.S. (2016). Assessment of the Impact of Recreational Nature Management on the Population of Orthoptera in the Katunsky Recreation Area of the Republic of Altai. Scientific Review. Biological Sciences, 6, 76-80.

Laptev, V.A., Lapteva, T.O., \& Malkov, P.Yu. (2016). Impact of Recreational Nature Management on Biomass Lyumbricid and Aboveground Phytomass of Grass Cover in Some Landscapes of the Katunsky Recreation Area of the Altai Republic. Sciences of Europe, 9, 7-10.

Malkov, P.Y. (2005). Quantitative Analysis of Biological Data. Gorno-Altaisk: RIO GAGU.

Malkov, P.Yu. (2016). The Impact of Recreational Nature Management on the Biotopic Groupings of Diurnal Butterflies (on the Example of the Katunsky Recreation Area of the Altai Republic). International Journal of Applied and Fundamental Research, 9(2), 252-256.

Malkov, Y.P. (1994). To the Method of Accounting for the Clavaceous Lepidoptera. In: Animal World of the AltaiSayan Mountainous Country. Gorno-Altaisk: Publishing House of the Gorno-Altai State University, 33-36.

Novikov, I.S. (2004). Morphotectonics of Altai. Moscow: Publishing House of the SB RAS.

Pavlova, K.S. (2015). Evaluation of the Geo-Ecological Consequences of Unorganized Mass Recreation in the Katunsky Recreation Area of the Altai Republic. Novosibirsk: Institute of Water and Ecological Problems SB RAS.

Pavlova, K.S., Robertus, Yu.V., \& Kivatskaya, A.V. (2013). The Nature of Changes in the Properties and Composition of Soils in Recreational Areas (on the Example of the Katunsky District of the Altai Republic). The World of Science, Culture and Education, 38(1), 338-342.

Pavlova, K.S., Robertus, Yu.V., Kivatskaya, A.V., \& Shevchenko, G.A. (2012). New Data on the State of the Stand in the Katunsky Recreation Area (Altai Republic). Natural Resources of Gorny Altai, 1-2, 119-121.

Pesenko, Yu.A. (1982). Principles and methods of quantitative analysis in faunistic studies. Moscow: Nauka.

Ravkin, Yu.S., \& Livanov, S.G. (2008). Factor Zoogeography: Principles, Methods and Theoretical Ideas. Novosibirsk: Nauka.

Ravkin, Yu.S., Livanov, S.G., \& Pokrovskaya, I.V. (1999). Monitoring the Diversity of Vertebrates in Specially Protected Natural Territories. In: Organization of Scientific Research in Reserves and National Parks. Moscow: Nauka, 103-142.

Rysin, L.P., \& Zolotova, F.N. (1968). To the Method of Determining the Productivity of the Above-Ground Part of the Grass Cover. In: Complicated Forests of Coniferous-Deciduous Forests and Ways of Farming in the Park and Forest Conditions of the Moscow Region. Moscow: Nauka, 138-144.

Sergeev, M.G. (2009). Hortobiont Arthropods in the Terrestrial Ecosystems of the West Siberian Plain: Estimates of Carbon Stocks. Bulletin of the Novosibirsk State University. Biology, clinical medicine, 9(4), 71-74.

Shchukina, E.N. (1960). Patterns of Placement of Quaternary Sediments and Their Stratigraphy on the Territory of Altai. Proceedings of the Geological Institute of the USSR Academy of Sciences, 26, 127-164.

Shitikov, V.K. (2012). Using Randomization and Bootstrap when Processing the Results of Environmental Observations. Principles of Ecology, 1(1), 4-24.

Sobansky, G.G. (2008). Beasts of Altai. Part 1. Large Predators and Ungulates. Moscow: KMK.

Sukhova, M.G., Zhuravleva, O.V., Kocheeva, N.A., Minayev, A.I., Karanin, A.V., Bolbukh, T.V., Nikolchenko, Yu.N., Bakulin, A.A., \& Roldugin, V.V. (2014). The Natural Climatic Conditions for the Economic Activity in Mountain Areas (in the Case of the Altai Republic). Life Science Journal, 11, 664-668.

Sukhova, M.G., Zhuravleva, O.V., Vinokurov, Y.I., Chernova, E.O., \& Kaizer, M.I. (2018). Recreation and Bioclimatic Specifics of Landscapes of the Central and South-Eastern Altai. Periodico Tche Quimica, 15(Special Issue 1), 537-547.

Thomas, J.A. (1983). A Quick Method for Estimating Butterfly Numbers During Surveys. Biological Conservation, 27, 195-211.

Travkina, M.Yu. (2002). Regulated Tourism and Recreation in the National Parks of Russia. Moscow: Wildlife Conservation Center Publishing House.

Van der Duim, R., \& Caalders, J. (2002). Biodiversity and Tourism: Impacts and Interventions. Annals of Tourism Research, 29(3), 743-761.

Vozniychuk, O.P. (2016). Assessment of the Nature of the Impact of Tourist Nature on the Population of Amphibians and Reptiles Katunsky Recreational District of the Republic of Altai. Interactive Science, 10, 18-23.

Zhuravleva, O.V., Sukhova, M.G., Karanin, A.V., \& Malkov, P.Yu. (2018). Relative Sustainability of the Altai Transborder Ecosystems. Periodico Tche Quimica, 15(30), 660-669.

Submitted:

25.04.2019
Revised:

10.09.2019
Accepted and published online 12.09.2019 